\title{
Lymphocytes to Non-Squamous Epithelial Cells Ratio Measurement
}

National Cancer Institute

\section{Source}

National Cancer Institute. Lymphocytes to Non-Squamous Epithelial Cells Ratio

Measurement. NCI Thesaurus. Code C135430.

The determination of the ratio of lymphocytes compared to non-squamous epithelial

cells present in a sample. The measurement may be expressed as a ratio or percentage. 